\title{
Novel Oxidation of Aromatic Aldehydes Catalyzed by Preyssler's Anion, $\left[\mathrm{NaP}_{5} \mathrm{~W}_{30} \mathrm{O}_{110}\right]^{14-}$
}

\author{
F. F. Bamoharram, ${ }^{*}$ a M. Roshani, ${ }^{a}$ M. H. Alizadeh, ${ }^{b}$ H. Razavi ${ }^{c}$ and M. Moghayadi ${ }^{a}$ \\ ${ }^{a}$ Department of Chemistry, Islamic Azad University-Mashhad Branch, Mashhad, Iran \\ ${ }^{b}$ Department of Chemistry, Ferdowsi University of Mashhad, Mashhad, Iran \\ ${ }^{c}$ Department of Chemistry, Georgetown University, U.S.A.
}

\begin{abstract}
$\mathrm{O}$ ânion de Preyssler, $\left[\mathrm{NaP}_{5} \mathrm{~W}_{30} \mathrm{O}_{110}\right]^{14-}$, catalisa a oxidação de aldeídos aromáticos aos correspondentes ácidos carboxílicos, na presença do agente oxidante peróxido de hidrogênio, sob irradiação de micro-ondas ou à temperatura de $70^{\circ} \mathrm{C}$. A atividade catalítica do catalisador de Preyssler, tanto em fase homogênea quanto suportado em sílica, foi comparada com a de algumas estruturas Keggin. Nossos dados indicam que o tungstopentafosfato de sódio 30, conhecido como ânion de Preyssler, o qual possui alta estabilidade hidrolítica (na faixa de $\mathrm{pH}$ de 0 a 12) e térmica, é o melhor catalisador, levando a bons rendimentos e alta seletividade. Sob irradiação de micro-ondas, esse poliânion suportado em $\mathrm{SiO}_{2}$ mostrou-se excelente catalisador das reações de aldeídos que apresentam baixo fator de perda, em 1-2 min (o fator de perda é uma medida da capacidade do material em dissipar energia). Os efeitos de vários parâmetros nos rendimentos dos ácidos carboxílicos foram estudados, tais como: tipo de catalisador, natureza do substituinte no aldeído e temperatura.
\end{abstract}

Preyssler's anion, with formula $\left[\mathrm{NaP}_{5} \mathrm{~W}_{30} \mathrm{O}_{110}\right]^{14-}$, catalyzes the oxidation of aromatic aldehydes to related carboxylic acids by hydrogen peroxide as oxidizing agent, under microwave irradiation, or at $70{ }^{\circ} \mathrm{C}$. Both homogeneous and heterogeneous Preyssler's catalysts (as $\mathrm{H}_{14}\left[\mathrm{NaP}_{5} \mathrm{~W}_{30} \mathrm{O}_{110}\right]$ ) were used and had their activity compared with those of some Keggin structures. Our data indicate that Sodium30-tungsto pentaphosphate, the so-called Preyssler's anion, with high hydrolytic ( $\mathrm{pH}=0-12)$ and thermal stability is the best catalyst with high yield and good selectivity. Under microwave irradiation, this polyanion supported on $\mathrm{SiO}_{2}$ was found to be an excellent catalyst for aldehydes with low loss factor in 1-2 min (the loss factor is a measure of the ability of the material to dissipate energy). The effects of various parameters, including catalyst type, nature of the substituent in the aldehyde and temperature, on the yield of the carboxylic acids were studied.

Keywords: Preyssler's anion, catalyst, heteropolyacid, oxidation, benzaldehyde, benzoic acid

\section{Introduction}

Catalysis by solid acid catalysts and related compounds is a field of increasing importance. Among solid acid catalysts, heteropolyacids have attracted much attention. ${ }^{1-5}$ Heteropolyacids catalyze a wide variety of reactions in homogeneous and heterogeneous phases offering strong options for more efficient and cleaner processing compared to conventional mineral acids., ${ }^{6,7}$

Much attention has been devoted to the catalytic behavior of the Keggin structure and its derivatives. ${ }^{8-10}$ Although Keggin type polyoxoanions and their derivatives have been widely studied as catalysts, the application of

* e-mail: abamoharram@yahoo.com; fbamoharram@mshdiau.ac.ir
Preyssler's anion has been very limited. ${ }^{11}$ In some cases there have been reports of no catalytic capability. ${ }^{12}$

Oxidation of benzaldehydes to related carboxylic acids is important and has been studied by many researchers. ${ }^{13}$ Mizuno and coworkers examined the oxidation of octanal by $\mathrm{O}_{2}$ with heteropolyacids including nickel and iron. ${ }^{14}$ Ishii and coworkers reported oxidation of aldehydes to carboxylic acids catalyzed by transition metal-substituted heteropolyacids. ${ }^{15}$ Zamaraev and coworkers reported the catalytic properties of some salts of Keggin heteropolyacids including cobalt. ${ }^{16}$ Although most of the works have dealt with metal-substituted heteropolyanions with Keggin structures, no catalytic activity has been reported for Preyssler's anion. 
This polyanion is remarkable due to its physicochemical properties that are important in catalytic processes. Some important features of this polyanion are: stability in the $\mathrm{pH}$ range from 0 to 12 , thermal stability, rendering high temperature reactions possible, and easy recovery of both pure and supported catalysts. ${ }^{17}$

In continuation of our research on the syntheses and application of heteropolyacids in organic syntheses, ${ }^{17-22}$ and due to the importance of derivatives of benzoic acid in medicine and industry, we hereby report the applicability of Preyssler's anion for efficient oxidation of aromatic aldehydes to the corresponding carboxylic acids. The major aim of the work described herein "is the design and development of applications for Preyssler's catalyst".

We have studied the catalytic behavior of this polyanion, pure and supported on silica under reflux, and under microwave irradiation. We also compared the efficiencies of Keggin's and Preyssler's catalysts for the oxidation of benzaldehydes. Oxidation of substrates in the absence of the catalyst proceeds with lower yield and longer reaction time. What is of interest to us is the fact that Preyssler's anion, with exclusive properties, is an effective catalyst surpassing the Keggin heteropolyacids in these reactions. This behavior is in accordance with our previous results of esterification reactions. ${ }^{20,22}$ Also our data show that, while in most reactions, benzaldehydes with electron-withdrawing substituents are thought to be hard-oxidising aldehydes, in the presence of Preyssler's catalyst, product yields are highest with electron-withdrawing substituents.

\section{Experimental}

\section{Reagents}

Keggin heteropolyacids and benzaldehydes were commercially available chemicals. $\mathrm{H}_{14}\left[\mathrm{NaP}_{5} \mathrm{~W}_{30} \mathrm{O}_{110}\right]$ was prepared according to the literature. ${ }^{17}$ The silica gel powder with mean particle size $15 \mu \mathrm{m}$ was purchased from Merck Company and was used as the catalyst support.

For the preparation of supported Preyssler's anions, 2.5 $\mathrm{g}$ of silica was suspended in $20 \mathrm{~mL}$ of water and then to this suspension the heteropolyacid in different loadings of tungsten was added. After stirring the heterogeneous solutionsupport mixture, the solvent was evaporated, samples were dried at $120^{\circ} \mathrm{C}$ and the catalysts were calcined at $250{ }^{\circ} \mathrm{C}$ in a furnace prior to use. Acetonitrile and hydrochloric acid have been acquired from commercial sources and were used without further purification. Hydrogen peroxide was obtained from Merck Company and was standardized by well-known methods (Hydrogen Peroxide Product Information Manual, Analytical Procedure).

\section{Apparatus}

An LG-804 microwave was used for all experiments. ${ }^{1}$ HNMR spectra were recorded on an FT - NMR Brucker $100 \mathrm{MHZ}$ Aspect 3000. IR spectra were recorded on a Buck 500 Scientific Spectrometer (KBr Pellets). Mass spectra were obtained with a Massens POEKTRO METER $\mathrm{CH}$ - 7A VARIN MAT BREMEN spectrometer.

Recommended procedure for the oxidation reactions of benzaldehydes catalyzed by Preyssler's catalyst

i) All reaction mixtures were refluxed in a $10 \mathrm{~mL}$ twonecked round-bottom flask equipped with magnetic stirrer, reflux condenser, and thermometer. In all cases, a catalyst $\left(10^{-5} \mathrm{~mol}\right)$ was added to a mixed solvent (acetonitrile in water) and benzaldehyde $\left(10^{-3} \mathrm{~mol}\right)$. The reaction mixture was stirred and refluxed for $8 \mathrm{~h}$ at $70{ }^{\circ} \mathrm{C}$. At equal intervals, $30 \%$ hydrogen peroxide $(0.03 \mathrm{~mol})$ was added $(0.5 \mathrm{~mL})$. To the final mixture, a 5\% aqueous solution of $\mathrm{NaHCO}_{3}$ was added and the mixture was filtered. The carboxylic acids were precipitated by adding $2 \mathrm{~mol} \mathrm{~L}^{-1} \mathrm{HCl}$ to the filtrate. The solid product was collected and washed with water and recrystallized in ethanol. The products were charactrized by comparison of their spectroscopic (IR, ${ }^{1}$ HNMR, Mass) data, and melting points with those of authentic samples. ii) Reactions were carried out in a 10 $\mathrm{mL}$ round-bottom flask equipped with magnetic stirrer and a thermometer for $8 \mathrm{~h}-4$ days at various temperatures, including room temperature $\left(25^{\circ} \mathrm{C}\right)$. Other conditions were the same as the reflux conditions already stated. iii) Under microwave irradiation, benzaldehyde $\left(10^{-3} \mathrm{~mol}\right)$, supported catalyst $(0.04 \mathrm{~g})$ and hydrogen peroxide $(2 \mathrm{~mL})$ were mixed throughly in a small beaker. The reaction mixture was placed in a microwave oven and irradiated for 1-2 min at $1100 \mathrm{~W}$. After cooling to room temperature and filtering of the mixture, the procedure was the same as above.

\section{Results and Discussion}

\section{Effect of the substituent}

The effects of various substituents on the yields of produced carboxylic acids have been examined in the presence of Preyssler's catalyst. Data in Table 1 show that not only the nature of the substituent is important, but so is its position. As examples of electron-withdrawing groups, bromo, chloro and nitro substituted benzaldehydes were chosen and were converted to their corresponding carboxylic acids. Methyl and hydroxy groups were chosen as electron-donating groups. 
Table 1. Yields of the oxidation reactions of benzaldehydes catalyzed by $\mathrm{H}_{14}\left[\mathrm{Na} \mathrm{P} \mathrm{P}_{5} \mathrm{~W}_{30} \mathrm{O}_{110}\right]$

\begin{tabular}{llcc}
\hline Entry & Substrate & $\begin{array}{c}\text { Percentage yield } \\
\text { of benzoic acids }\end{array}$ & $\%$ Selectivity \\
\hline 1 & 4-Chloro benzaldehyde & 100.0 & 100 \\
2 & 4-Bromo benzaldehyde & 91.0 & 100 \\
3 & 4-Nitro benzaldehyde & 84.5 & 100 \\
4 & 4-Methyl benzaldehyde & 73.5 & 96 \\
5 & 3-Methyl benzaldehyde & 70.0 & 98 \\
6 & 2-Methyl benzaldehyde & 13.5 & 95 \\
7 & 2-Hydroxy benzaldehyde & Trace & 90 \\
8 & 3-Hydroxy benzaldehyde & Trace & 90 \\
9 & 4-Hydroxy benzaldehyde & Trace & 91 \\
\hline
\end{tabular}

Reaction conditions: catalyst, $10^{-5} \mathrm{~mol}$; substrate, $10^{-3} \mathrm{~mol}$; solvent: acetonitrile $(2 \mathrm{~mL}), \mathrm{H}_{2} \mathrm{O}(3 \mathrm{~mL})$, hydrogen peroxide $(0.03 \mathrm{~mol})$; reflux for $8 \mathrm{~h}$.

The results indicate that the yield with chlorobenzaldehyde was higher (entry 1). The hydroxy benzaldehydes with poor yields were converted to their carboxylic acids under these conditions (entry 7). In all cases his yield of carboxylic acids increased in the following order: 4-chlorobenzoic acid > 4-bromobenzoic acid > 4nitrobenzoic acid $>4$-methyl benzoic acid $>3$-methylbenzoic acid $>$ 2-methylbenzoic acid > 2-hydroxy, 3-hydroxy and 4hydroxybenzoic acids.

In the oxidation of these aldehydes to the related carboxylic acids, electron-withdrawing substituents result in higher yields than electron-donating substituents. We thought that, under the conditions used, electron-donating substituents were probably overoxidised, but the spectroscopic data and GC analysis did not show overoxidation. Therefore while in most reactions, benzaldehydes with electron-withdrawing substituents are thought to be hard-oxidising aldehydes, in the presence of Preyssler's catalyst, product yields are higher with electron-withdrawing substituents.

Comparison of 2, 3, and 4 positions in methyl benzaldehydes shows that, not only the nature of the substituent influences the yield, but so does its position. Yields increased in this order: $2<3<4$. The largest effect is found for the methyl group at para position.

\section{Effect of the catalyst structure}

The results of catalytic oxidation of mono-substituted benzaldehydes by hydrogen peroxide (with Preyssler's anion and the Keggin series as catalyst), at $70^{\circ} \mathrm{C}$ are shown in Figure 1 (data for products with poor yield are not tabulated). In the Keggin series including $\mathrm{H}_{3}\left[\mathrm{PW}_{12} \mathrm{O}_{40}\right], \mathrm{H}_{4}\left[\mathrm{SiW}_{12} \mathrm{O}_{40}\right]$, and $\mathrm{H}_{3}\left[\mathrm{PMo}_{12} \mathrm{O}_{40}\right]$, heteropolyacid $\mathrm{H}_{3}\left[\mathrm{PW}_{12} \mathrm{O}_{40}\right]$ shows the highest catalytic activity. In other words, $\mathrm{H}_{3}\left[\mathrm{PW}_{12} \mathrm{O}_{40}\right]$ is the best catalyst and the highest yield of carboxylic acids is obtained when the oxidation is carried out by it. In general, the Keggin type catalysts were less efficient than Preyssler's anion.

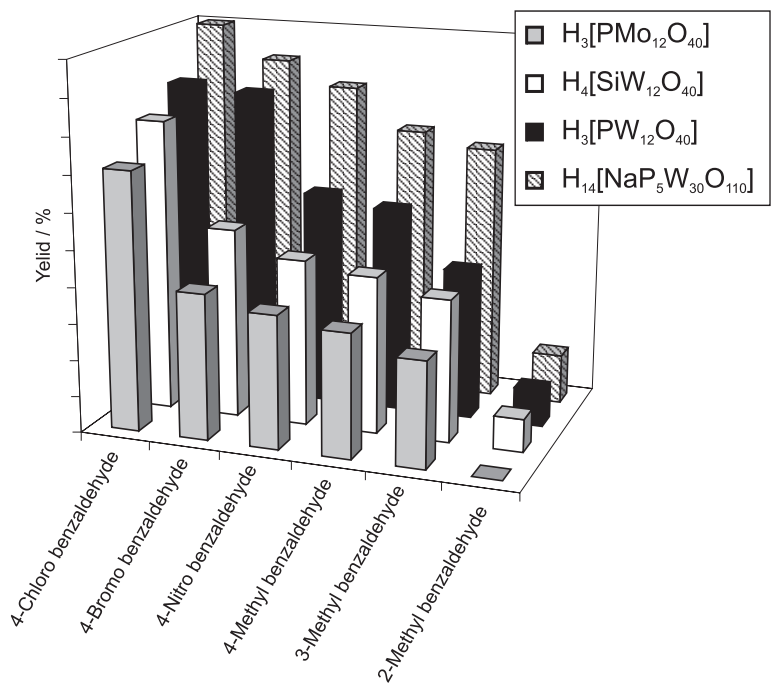

Figure 1. Comparison between Keggin and Preyssler catalysts at $70{ }^{\circ} \mathrm{C}$.

However, the results indicate that the highest yield of carboxylic acids is obtained when the oxidation of substrates is carried out with $\mathrm{H}_{14}\left[\mathrm{NaP}_{5} \mathrm{~W}_{30} \mathrm{O}_{110}\right]$ as catalyst. This behavior is found to be quite general. The results point out that the catalytic effectiveness may be enhanced as the number of tungsten atoms (or the number of protons) is increased. Both possibilities stand to reason. The larger number of protons may lower the activation barrier to the oxidation reaction. The large anion with the larger number of tungsten atoms, also provides many "sites" on the oval-shaped molecule that are likely to render the catalyst effective.

It is probable that radical products from the decomposition of hydrogen peroxide $\left(\mathrm{HO} \bullet\right.$ and $\left.\mathrm{HO}_{2} \cdot\right)$ act as the benzaldehyde oxidants in the Preyssler's anion catalyzed oxidation at $70{ }^{\circ} \mathrm{C} .23-25$

\section{Effecct of the temperature}

With all catalysts and substrates, yields of products are a function of temperature. The results show that carboxylic acids yield increased as the reaction temperature was raised.

As expected, under all conditions Preyssler's anion showed the highest yields for all substrates. The results for this catalyst are compared at room temperature (lowest temperature, $25^{\circ} \mathrm{C}$ ) and at $70{ }^{\circ} \mathrm{C}$ (highest temperature) in Figure 2. Some controlled experiments, at room temperature, showed that the yields of carboxylic acids are also a function of time: the longer the time, the higher the yield.

\section{Effect of microwave irradiation}

In recent years, a practical dimension to the microwave heating protocols has been added by 


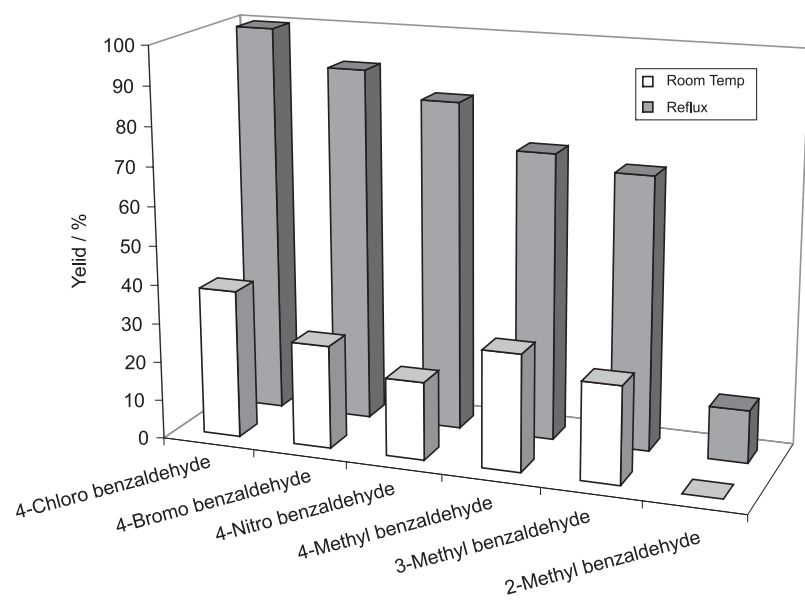

Figure 2. Comparison between room temperature and reflux conditions $\left(70^{\circ} \mathrm{C}\right)$.

accomplishing reactions on solid supports under solventfree conditions..$^{26,27}$ These solvent-free microwaveassisted reactions provide an opportunity to work with open vessels, thus avoiding the risk of high pressure development and increasing the potential of such reactions to large scale production.

Oxidation of aldehydes is a surface type reaction and with Preyssler's anion produces the highest yields (Table1 and Figure1). For the first time, we describe herein our results on this environmentally benign microwave approach for the synthesis of aromatic carboxylic acids in the presence of supported Preyssler's anion. We show that the silica-supported Preyssler's catalyst, in solventfree conditions, renders effective the aldehyde oxidation to carboxylic acid in the presence of hydrogen peroxide under microwave irradiation, in 1-2 min.

In order to have a proper comparison, all reactions were performed under similar conditions (110 s and $1100 \mathrm{~W})$.

The catalysts with different initial $\mathrm{H}_{14}\left[\mathrm{NaP}_{5} \mathrm{~W}_{30} \mathrm{O}_{110}\right]$ loadings on silica were prepared for the oxidation of benzaldehydes to carboxylic acids under microwave irradiation. The results are shown in Figure 3.

The results show that, 4-chlorobenzaldehyde could be easily oxidized but hydroxy benzaldehydes could not. Other mono-substituted benzaldehydes show different behaviors. It is proposed that this behavior is due to loss factor of the substrates.

Microwaves cause molecular motion by migration of ionic species and/or rotation of dipolar species. Microwave heating of substances to a great extent depends on its dissipation factor which is the ratio of dielectric loss or, loss factor due to the dielectric constant of the material. The dielectric constant is a measure of the ability of the material to retard microwave energy as it passes through; loss factor is a measure of the ability of the material to

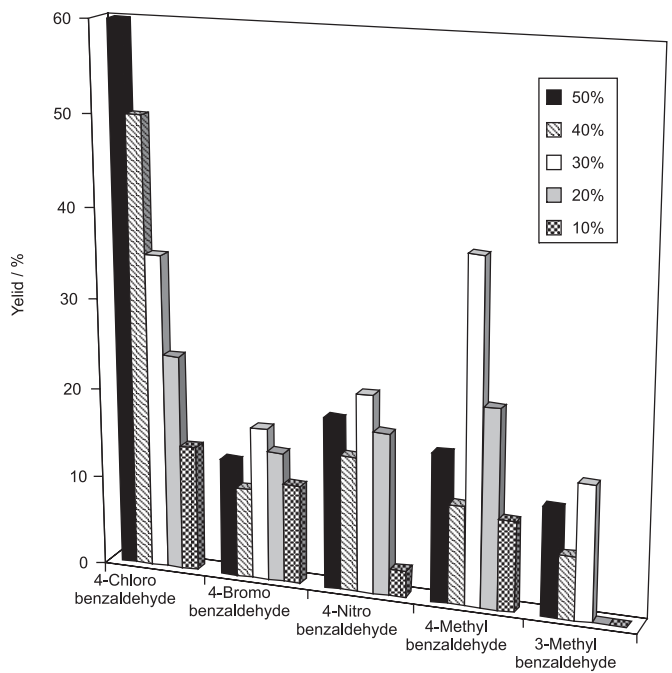

Figure 3. Yields of the oxidation reactions of benzaldehydes catalyzed by $\mathrm{H}_{14}\left[\mathrm{NaP}_{5} \mathrm{~W}_{30} \mathrm{O}_{110}\right]$ on silica, under microwave irradiation.

dissipate the energy. In other words, loss factor represents the amount of input microwave energy that is lost in the material by being dissipated as heat. Therefore, a material with high loss factor is easily heated by microwave energy. Hydroxy benzaldehydes appear to have the highest loss factor in the series that we have examined.

The reason for the differences observed in the efficiency of the oxidation of the various benzaldehydes by silica supported Preyssler's catalyst is not clear. However, it is supposed that microwave heating involves direct absorption of energy by functional groups that bear ionic conductivity or a dipole rotation effect which is then released to the surrounding solution. The different functional groups have therefore different activities with the surrounding reactants, compared with when they are simply incubated with the reactants at the same temperature.

As illustrated in Figure 3, the catalyst with the smallest tungsten loading gave the worst results, and this is attributed to the decrease in the total number of available active catalytic sites for the reaction. However, selectivity was independent of catalyst loading. The oxidation of aldehydes is a surface type reaction ${ }^{28}$ which proceed on the outer surface of the supported heteropolyacid.

In all cases, the supported polyacid is less active than the unsupported one, which indicates that there is a direct interaction between the heteropolyacid and the support surface, possibly via an acid-base reaction. The interaction between the heteropolyacid and the silica $\mathrm{OH}$ surface groups therefore would bring the decrease of acidity and redox property of the heteropolyacid. In view of the difference in softness or hardness of the hydroxyl groups of support and heteropolyacid, the reaction between heteropolyanion and hydroxyl on the support may proceed according to exchange 
mechanism (e.g. hard-hard reaction) or coordination of protonated surface hydroxyl with heteropolyanion in solution to form an outer sphere surface complex, instead of exchange reaction (e.g. hard-soft reaction). ${ }^{29}$

\section{Conclusions}

For the first time, by an inexpensive solid acid catalyst and an easily prepared Preyssler's acid, oxidation of benzaldehydes with electron-withdrawing and electrondonating groups to the corresponding carboxylic acids have been studied. The results show that the catalyst type, the nature and positions of substituents and temperature are important factors.

Our results suggest that, while in most reactions Keggin type polyanions are thought to be better catalysts, $\mathrm{H}_{14}\left[\mathrm{NaP}_{5} \mathrm{~W}_{30} \mathrm{O}_{110}\right]$ is a more efficient catalyst and product yields are always higher with Preyssler's catalyst. The results also show that under microwave irradiation, the oxidation readily proceeds over silica-supported Preyssler's catalysts with different tungsten loadings in solvent-free conditions in a very short time (1-2 min) and that the loss factor of substrates is important. This can be due to the polar nature of the reaction intermediates that couple efficiently with microwaves and hence increase the yield and accelerate the rate. Clearly, this method minimizes the longer reaction times required under thermal conditions.

Important features of this catalyst (of high surface area), simple experimental set-up and procedure, demonstrates the applicability of Preyssler's anion for some reactions that require solid catalysts with strong acidic properties, highly thermal stability and functionality over a wide range of $\mathrm{pH}$.

\section{References}

1. Matvee, K. I.; Kinet. Catal. 1977, 18, 862.

2. Ono, Y. In Perspectives in Catalysis; Thomas, J. M.; Zamaraev, K. I., eds.; Black well: London, 1992, p. 431.

3. Kozhevnikov, I. V.; Mateev, K. I.; Appl. Catal. 1983, 5, 135; Kozhevnikov, I. V.; Mateev, K. I.; Russ. Chem. Rev. 1982, 51, 1075.

4. Kozhevnikov, I. V.; Russ. Chem. Rev. 1987, 56, 811.

5. Kozhevnikov, I. V.; Stud. Surf. Sci. Catal. 1994, 90, 21; Kozhevnikov, I. V.; Russ. Chem. Rev. 1993, 62, 473.

6. Izumi,Y.; Urabe, K.; Onaka, M.; Zeolite, Clay and Heteropoly Acid in Organic Reactions, Kodansha / VCH: Tokyo, 1992.

7. Mizuno, T. N.; Misono, M.; Adv. Catal. 1996, 41, 113.

8. Misono, M.; Nariji, N.; Appl. Catal. 1990, 64, 1.

9. Pope, M. T.; Heteropoly and Isopoly Oxometalates, Springer: Berlin, 1983.
10. Langpape, M.; Millet, J. C. M.; Appl. Catal. 2000, 89, 200

11. Harrup, M. K.; Hill, C. L.; Inorg. Chem. 1993, 33.

12. Fox, M. A.; Cardona, R.; Gaillard. E.; J. Am. Chem. Soc. 1987, 109, 6347.

13. Matsumoto, Y.; Asami, M.; Hashimoto, M.; Misono, M.; J. Mol. Catal. 1996, 114, 161.

14. Mizuno, N.; Hirose, T.; Tateishi, M.; Iwamoto, M.; J. Mol. Catal. 1994, 88, 125.

15. Hamamoto, M.; Nakayama, K.; Nishiyama, Y.; Ishii, Y.; J. Org. Chem. 1993, 58, 6421.

16. Kholdeeva, O.A.; Khavrutskii, I.V.; Romannikov, V.N.; Tkachev, A.V.; Zamaraev, K.I.; Abstracts of the $3^{\text {th }}$ World Congress on Oxidation Catalysis, Grasselli, R.K.; Oyama, S.T.; Gaffney, A.M.; Lyons, J.E., eds., Elsevier: Amsterdam, 1997.

17. Alizadeh, M. H.; Harmalker, S. P.; Jeanenin, Y.; Martin - Frere, J.; Pope, M. T.; J. Am. Chem. Soc. 1985, 107, 2662.

18. Alizadeh, M. H.; Razavi, H.; Bamoharram, F. F.; Daneshvar, K.; J. Mol. Catal. 2003, 206, 89.

19. Arabi, M.; Mohammadpour Amini, M.; Abedini, M.; Nemati, A.; Alizadeh, M.; J. Mol. Catal. 2003, 200, 105.

20. Alizadeh, M. H.; Razavi, H.; Bamoharram, F. F.; Hassanzadeh, M. K.; Kinet. Catal. 2003, 44, 524.

21. Alizadeh, M. H.; Razavi, H.; Mohammadi Zonoz, F.; Mohammadi, M. R.; Polyhedron 2003, 22, 933.

22. Heravi, M. M.; Derikvand, F.; Bamoharram, F. F.; J. Mol. Catal. 2005, 242, 173; Bamoharram, F. F.; Heravi, M. M.; Roshani, M.; Jahangir, M.; Gharib, A.; Appl. Catal. 2006, 302, 42; Bamoharram, F. F.; Heravi, M. M.; Roshani, M.; Tavakoli, N.; J. Mol. Catal. 2006, in press; Heravi, M. M.; Motamedi, R.; Seifi, N.; Bamoharram, F. F.; J. Mol. Catal. 2006, in press; Heravi, M. M.; Bakhtiari, Kh.; Bamoharram, F. F.; Catal. Commun. 2006, in press; Bamoharram, F. F.; Heravi, M. M.; Roshani, M.; Gharib, A.; Jahangir, M.; J. Mol. Catal. 2006, in press; Heravi, M. M.; Bakhtiari, Kh.; Bamoharram, F. F.; Catal. Commun. 2006, in press; Bamoharram, F. F.; Heravi, M. M.; Roshani, M.; Akbarpour, M.; unpublished results.

23. Yamase, T.; Ichicawa, E.; Asai, Y.; Kanai, S.; J. Mol. Catal. 1996, 114, 237.

24. Kuznetsova, L. I.; Detusheva, L. G.; Fedotov, M. A.; Likholobov, V. A.; J. Mol. Catal. 1996, 111, 81.

25. Kuznetsova, L. I.; Detusheva, L. G.; Kuznetsova, N. I.; Fedotov, M. A.; Likholobov, V. A.; J. Mol. Catal. 1997, 117, 389.

26. Thostenson, E. T.; Chou, T. W.; Composites 1999, 30, 1055.

27. Majetich, G.; Hicks, R.; Radiat. Phys. Chem. 1995, 45, 567.

28. Mizuno, N.; Tateishi, M.; Iwamoto, M.; J. Catal. 1996, 163, 87.

29. Wu, Y.; Ye, X.; Yang, X.; Wang, X.; Chu, W.; Hu, Y.; Ind. Eng. Chem. Res. 1996, 35, 2546.

Received: May 25, 2005 Published on the web: March 13, 2006 